Int. J. Electrochem. Sci., 14 (2019) 7470 - 7486

\title{
Electrochemical Sensor Based on Self-doped Polyaniline with Guest-induced Binding Sites for Detection of Lead(II) Ion
}

\author{
Jahangir Shojaei, Ali Reza Zanganeh* \\ Department of Chemistry, Shahreza Branch, Islamic Azad University, Shahreza, Iran \\ *E-mail: ar.zanganeh@gmail.com, ar.zanganeh@iaush.ac.ir, ar zanganeh@yahoo.com
}

doi: $10.20964 / 2019.08 .66$

Received: 14 October 2018 / Accepted: 26 February 2019 / Published: 30 June 2019

\begin{abstract}
An electrochemical approach towards developing a lead(II) ion selective polymer is presented. A poly(aniline-co-3-aminobenzenesulfonic acid), P(Ani-co-3ABSA), membrane would be reconciled with the peculiarities of lead(II) ions by incorporating them. It seems that consecutive embedding/ejecting of lead(II) into-from the mass of P(Ani-co-3ABSA) coating, correspondingly templates the coating towards lead(II) ion. This method results in a highly selective sensor for the measurement of lead(II) ion. The optimal conditions for sensor operation were ascertained. The surface morphology of the freshly synthesized, templated and templated-preconcentrated P(Ani-co-3ABSA) membranes were explored by SEM. The interference effect on the voltammetric response with coexisting ions was also investigated. The developed sensor was applied for lead(II) determination by pre-concentration/differential pulseanodic stripping voltammetry in concentrations of $1.0 \mathrm{nM}$ to $0.1 \mathrm{mM}$ and by potentiometric method in concentrations of $10.0 \mathrm{nM}$ to $1.0 \mathrm{mM}$.
\end{abstract}

Keywords: Self-doped polyaniline; Recognition elements; Pb measurement; voltammetry; potentiometry

\section{$\underline{\text { FULL TEXT }}$}

(C) 2019 The Authors. Published by ESG (www.electrochemsci.org). This article is an open access article distributed under the terms and conditions of the Creative Commons Attribution license (http://creativecommons.org/licenses/by/4.0/). 